\title{
66- Defence mechanisms in literature: Wuthering Heights and Yeryüzünde bir Melek
}

\section{Senem ÜSTÜN KAYA1}

APA: Üstün Kaya, S. (2021). Defence mechanisms in literature: Wuthering Heights and Yeryüzünde bir Melek. RumeliDE Dil ve Edebiyat Araştırmaları Dergisi, (25), 1079-1088. DOI: 10.29000/rumelide.1036624.

\begin{abstract}
The psychoanalytic approach in literary criticism can be perceived as an efficient way for the analyses of characters, events, and the impacts of society on personality development. As explained by Sigmund Freud (1962a), the struggle between the id (instincts) and the superego (society/environment) leads to conflicts for the ego (self) in actual life. In order to protect the ego from the undesirable experiences caused by the id, individuals tend to use 'defence mechanisms'. Defence mechanisms were first posited by Freud and strengthened by his daughter, Anna Freud in The Ego and the Mechanisms of Defence (1936). In actual life, individuals consult defence mechanisms to avoid anxiety, sorrow and frustration. Therefore, they could both obey the societal expectations and protect their egos from undesired feelings. Similar to individuals in real world, in fiction, authors protect their characters from harsh situations via certain defence mechanisms. Through these devices, readers could understand and interpret the clashes in narration. This comparative study aims to analyse the defence mechanisms used by two literary female figures from different cultures: Raziye in Ahmet Mithat Efendi's Yeryüzünde bir Melek (1878) and Catherine in Emily Brontë's Wuthering Heights (1847). The analysis examines and exemplifies how and why Raziye and Catherine use "denial" and "projection" as defence mechanisms. The study concludes that both female protagonists consult defence mechanisms for two reasons: to protect themselves in patriarchal societies and to avoid undesirable feelings of guilt, shame and sorrow.
\end{abstract}

Keywords: Defence mechanisms, psychoanalytic, comparative, Yeryüzünde bir Melek, Wuthering Heights

\section{Edebiyatta savunma mekanizmaları: Wuthering Heights ve Yeryüzünde bir Melek}

$\ddot{O} \mathbf{z}$

Edebi eleştiride psikanaliz yaklaşım, karakterler, olaylar ve toplum faktörlerinin kişilik gelişimine etkilerini incelemede etkin bir yaklaşım olarak kabul edilir. Sigmund Freud'un psikanaliz bağlamındaki çalışmalarında açıkladığı gibi, gerçek hayatta, alt benlik (dürtüler) ve üst benlik (toplum/çevre) arasındaki mücadele, benlik (öz) için çatışmalara yol açmaktadır. Alt benlik yüzünden oluşabilecek istenmeyen tecrübelerden benliği korumak için, bireyler, 'savunma mekanizmalarını' kullanmaya yatkındırlar. Psikolojide savunma mekanizmaları ilk olarak Sigmund Freud tarafindan geliştirilmiş ve bilim kadını olan kızı Anna Freud tarafından The Ego and the Mechanisms of Defence (1936) adlı çalışmada güçlendirilmiştir. Kaygı, üzüntü ve hayal kırıklığından korunmak ve toplumun beklentilerini karşılamak adına, bireyler gerçek hayatta, savunma mekanizmalarına başvururlar. Bu

Doç. Dr., Başkent Üniversitesi, İngiliz Dili Eğitimi ABD (Ankara, Türkiye), efesenem@yahoo.com, ORCID ID: oooooo01-6537-9769 [Araştırma makalesi, Makale kayıt tarihi: 17.11.2021-kabul tarihi: 20.12.2021; DOI: 10.29000/rumelide.1036624] 
sayede, hem toplumun kurallarına uymuş olurlar hem de istenmeyen duygulardan kendi benliklerini korurlar. Tıpkı gerçek dünyadaki bireyler gibi, edebi eserlerde, yazarlar, karakterlerini zor durumlardan savunma mekanizmaları aracılığıyla kurtarırlar. Bu mekanizmalar sayesinde, okuyucu anlatımın içindeki çelişkileri daha iyi anlar ve anlamlandırır. Bu karşılaştırmalı çalışma, edebi eserlerdeki savunma mekanizmalarının anlatımı nasıl derinleştirdiğini ve okuyucuya analiz olanağını sunduğunu örneklendirmek adına yapılmıştır. Bu çerçevede, bu çalışma, farklı kültürlerden iki edebi eserdeki kadın figürler tarafından kullanılan savunma mekanizmalarının analizini amaçlar. Analiz kısmını, Ahmet Mithat Efendi'nin Yeryüzünde bir Melek (1878) romanındaki Raziye ve Emily Brontë'un Wuthering Heights (1847) eserindeki Catherine karakterleri tarafindan kullanılan savunma mekanizmalarının karşılaştırmalı incelenmesi oluşturmaktadır. Bu bağlamda, bu çalışma, Raziye ve Catherine'in "inkâr" ve "yansıtma" kategorisindeki savunma mekanizmalarının nasıl ve neden kullandıklarını inceler. Çalışmada, her iki kadın ana karakterin savunma mekanizmalarını iki sebeple kullandığı sonucuna varılmıştır: erkek egemen toplumlarda benliklerini korumak ve suçluluk, utanç ve hüzün gibi istenmeyen duyguları önlemek.

Anahtar kelimeler: Savunma mekanizmaları, psikanalitik, karşılaştırma, Yeryüzünde bir Melek, Wuthering Heights

\section{Introduction}

The relationship between literature and psychoanalysis has always been foregrounded by the academic field of literary theory and criticism (Hossain 2017: 41). Psychoanalysis dates back to the period after the First World War, yet became prominent with the studies of Sigmund Freud, who based his theories on the relationship between the conscious and the unconscious human mind. Inspired by Freud, modern psychologists, Freud systematically developed the theory of the structure of human mind and emphasized the concept of 'the unconscious mind' as the primary source of human behavior (Rennison, 2001: 38-40).

Although the psychoanalytical approach to literature was initiated in the second half of the 19th century in France (Yücel 2000: 7), the reflection of Freud's influence in literature began with absurd drama and structuralism (Kraus 1982: 89). In his book The Ego and the Id (1923), Freud stated that the human mind was divided into two as the "conscious" and the "unconscious" and the "division of the psychical into what is conscious and what is unconscious is the fundamental premiss of psycho-analysis" (Freud 1962a: 3). Within this division, Freud categorized the human psyche into three levels: the ego, the id and the superego: "mental processes; and we call his ego" (Freud 1962a: 15) and the resistance of the ego against the repressed creates conflicts for the individual. The id is where the unconscious instincts and unknown desires are hidden in the ego, which is not separated from the id completely: "But the repressed merges into the id as well, and is simply a part of it. The repressed is only cut off sharply from the ego by the resistances of repression; it can communicate with the ego through the id" (Freud 1962a: 28). The id is repressed by the outer forces, particularly by the ego due to societal expectations. In other words, the ego refers to the reasonable part of the self while the id refers to the repressed passions in the unconscious of human mind (Freud 1962a: 15). The superego represents the orders (society, family, authority) that are outside the ego, which tries to balance the id and the superego. It is conveyed to the individual by the parents in the early childhood periods through the methods of reward and punishment. The superego represents "the ideal" for the ego (Freud 1962a: 15-17). As the individual becomes civilized in the society, social norms and concepts shape the self that is directed, repressed, and guided by the 
environment (Freud 1962a). The ego is constantly under the influence of the superego, which imposes the social codes and ideal goals.

Therefore, the environment had an undeniable impact on the psychological and emotional development of an individual who sought pleasure to fulfil his biological and psychological needs despite the inabilities to assess the reality of the external world (Freud 1962b: 14). The individual, thus, suffers from a sense of guilt and shame when he opposes society and its codes. Also, for Freud, the development of personality and its moral side of the personality starts at the first six years of life (Aytar 2005) and "consists initially of the rules of conduct set down by our parents" (Schultz \& Schultz 2017: 47). The superego, at this stage, controls the ego and directs the person to make proper choices, accepted and expected by the society (Rennison 2001: 39-40). In short, for Freud, the struggle between the self and the oppressive and restrictive environment could be accepted as the core of the problems for individuals.

Alfred Adler was a philanthropist who studied the relation between the individual and the society and emphasized the significance of "an essential cooperative harmony between the individual and the society" (Adler 1964: 29), which starts in the early stages of life. For Adler, based on social interactions, the life style and personality of an individual are shaped at the age of four or five (Schultz \& Schultz, 2017: 114). Similarly, Erik Erikson focused on the interaction between the ego and the normative expectations of the social environment: "a configuration [which] is gradually established by successive ego syntheses and resyntheses... It is a configuration gradually integrating constitutional givens, idiosyncratic libinal needs, favoured capacities, significant identifications, effective defences, successful sublimations, and consistent roles" (Erikson 1968: 163). For Erikson (1978), the identity stage is shaped during puberty and ends any time in the late teens.

All in all, based on the theories and studies of modern psychiatrists and psychologists, it would not be wrong to generalize that social norms, family, society and environment shape the personalities based on the social codes and roles at early ages (Schultz \& Schultz 2017). The first five years of life (Freud and Adler) and the adolescence period (Erikson) are the critical period for individuals to adapt to the environment and comply with societal expectations. When faced with obstacles, individuals defend their identities and status in society using certain mechanisms.

Freud is considered the first to state that anxiety was an obstacle to personality development, and "defence mechanisms" were psychological devices used to cope with anxiety (Taylor 2003). Based on the clinical studies, Sigmund Freud's daughter, Anna Freud strengthened the types of defence mechanisms of the ego in her book The Ego and the Mechanisms of Defence (1936). Anna Freud categorized the methods of defence mechanisms as ten: regression, repression, reaction-formation, isolation, undoing, projection, introjection, turning against the self, reversal and sublimation and explained the defence of the ego as:

\footnotetext{
The term 'defence' is the earliest representative of the dynamic standpoint in psychoanalytical theory. It occurs for the first time in 1894, in Freud's study 'The Defence Neuro-Psychoses' and is employed in this and several of his subsequent works... to describe the ego's struggle against painful or unendurable ideas or affects. Later, this term was abandoned and, as time went on, was replaced by that of 'repression' (Freud 1946: 45).
}

In its broadest definition, defence mechanisms refer to the automatically employed mechanisms that occur when a person faces undesirable feelings in life such as anxieties, frustrations or conflicts. These mechanisms or methods are the measures designed to "secure the ego and save it from experiencing 
'pain' or unendurable ideas" (Freud 1946: 74). Thus, such mechanisms emerge to protect the ego from anxieties and distress and assist "the ego in its struggle with its instinctual life" (Freud 1946: 73).

The relation between literature and psychoanalysis has always been deployed with the theories of modern psychologists. As an appreciated approach, psychoanalytical approach in literature provides interpretation of the interaction between conscious and unconscious states of literary characters. Similar to individuals in actual life, literary characters also struggle between the ego and the id, and thus, use some methods to protect themselves against undesirable situations. Psychoanalytic literary criticism, therefore, contributes to the analysis and interpretation of manners, thoughts and hidden feelings of characters, which provides readers insights for the hidden messages of authors. Although there are various studies based on the relation between literature and psychoanalysis, this study aims at a comparative analysis of two literary female figures: Raziye in Ahmet Mithat Efendi's Yeryüzünde bir Melek (1878) and Catherine in Emily Brontë's Wuthering Heights (1847). Within this scope, the analysis is based on the investigation of how Raziye and Catherine use "denial" and "projection" defence mechanisms to struggle with the internal and external forces.

\section{Yeryüzünde bir Melek and Wuthering Heights}

After the Industrial Revolution (1760-1840), Britain experienced changes in terms of economy, history, politics and social life. While the upper classes and land owners became wealthier, the working class had to deal with poverty, unemployment and suffering from the working conditions at factories, coal mines and industries. The writers and intellectuals of the period criticized the changing society, designed with materialistic values and class distinctions. The notable English novelist, Emily Brontë (1818-1848) was one of the most distinguishing female writers, who portrayed the social changes and gender issues in her writings. Brontë's only novel, Wuthering Heights (1847), reflects the gender segregations, inequalities in society and impacts of materialism during the Victorian era in the background of the turbulent love between Catherine and Heathcliff.

Catherine is one of the two children of the Earnshaws, the original tenants of the Wuthering Heights estate. Adopted by Mr. Earnshaw, the orphan Heathcliff grows up with the Earnshaw children, Hindley and Catherine. Heathcliff and Catherine develop intimacy and love for each other since their childhood. However, accepting the marriage proposal of Edgar Linton, Heathcliff leaves Wuthering Heights. When Heathcliff returns, for revenge, he marries Isabella, Edgar's sister and Catherine gives birth to Cathy before her death. After 17 years, Heathcliff manipulates his son, Linton to marry Cathy and with the death of Edgar, Linton becomes the owner of the Heights. The novel ends as the village locals report seeing the ghost of Heathcliff with Catherine's out on the moors.

In the 19th century, influenced by the changes in the western cultures, during Tanzimat Period, the Ottoman society experienced social and cultural changes due to westernization. The society underwent changes in gender roles, class perceptions and women's rights and many intellectuals and authors used fiction to educate the Ottoman readers about these changes. Ahmet Mithat Efendi, the "engineer of the society" (Kefeli 2013: 27), was accepted as one of the first advocators of women rights who focused on gender issues, arranged marriages and women's education.

In his novel, Yeryüzünde bir Melek (1878), Ahmet Mithat Efendi depicted the story of Şefik and Raziye, two lovers who struggle for their love due to the obstacles as familial issues and society. Similar to Catherine and Heathcliff, Şefik and Raziye grew up together in an estate. Şefik is an orphan adopted by 
Raziye's father, Mehmet Hulusi Efendi. However, Şefik leaves the estate for university education and moves to Paris and meanwhile Raziye marries İskender Bey on his father's will. However, after Şefik returns as a respectable doctor, the lovers meet secretly until Şefik is seduced by a fallen woman, Arife. Arife, for revenge, reports the police about Raziye and Şefik and the forbidden love is revealed. Şefik is exiled to Vidin and Raziye's husband divorces her. In poverty and misery, Raziye leads a life isolated by the society. The novel ends with the reconciliation of Şefik and Raziye and the suicide of Arife. In a parallel structure with Wuthering Heights, in Yeryüzünde bir Melek, the societal oppressions, significance of materialism and class distinctions are vividly apparent. In both novels, defence mechanisms are used by female protagonists that tend to both avoid frustration and sorrow and protect their egos from the societies.

\section{Analysis: Defence Mechanisms of Raziye and Catherine}

This part of the study involves the analysis of two texts, Yeryüzünde bir Melek and Wuthering Heights. The scope of the analysis of based on the some defence mechanisms, used by the female characters, Raziye and Catherine within the narration of the novels. Although Anna Freud categorized the defence mechanisms as regression, repression, reaction-formation, isolation, undoing, projection, introjection, turning against the self, reversal and sublimation, the analysis part of this study involves the examination of two defence mechanisms: denial and projection in Ahmet Mithat Efendi's novel Yeryüzünde bir Melek and Emily Brontë's Wuthering Heights. Denial is one of the best known defence mechanisms used when a situation is too challenging for an individual. Denial occurs when the individual both refuses to face reality and admit a truth to avoid anxiety, frustration and sorrow, caused by the society: "An ego which attempts to save itself anxiety and renunciation of instinct and to avoid neurosis by denying reality is overstraining this mechanism [denial]” (Freud 1946: 87).

As stated before, modern psychologists foregrounded the impacts of social environment on personality development at childhood (Adler 1964; Freud 1962b) or puberty (Erikson 1978). In the novels of Ahmet Mithat Efendi and Emily Brontë, this theory can be observed in the analysis of childhood and adolescence periods of Raziye and Catherine. In Yeryüzünde bir Melek, Şefik, as an orphan is raised in the estate of Raziye and they grow up together. Raziye and Şefik spend all their time together in childhood. However, Şefik is an outcast with his dark skin, recalling Asians and the society criticize the intimacy between these two children from different classes. When women in the estate judge and condemn their relation, Raziye rebels: "separating us from each other is like separating two siblings, Şefik. Judging us for our relation is as immoral as judging siblings" (Ahmet Mithat Efendi 2000: 193) 1 . Similarly, in Emily Brontë's Wuthering Heights, Heathcliff is an orphan, adopted by the Earnshaws and grows up with Catherine in the estate. Like Raziye, Catherine has deep feelings for the orphan boy and the greatest punishment for her was to be "kept away from Heathcliff". However, both Şefik and Heathcliff are considered as outcasts and accepted as inferior than Raziye and Catherine.

As they grow up, both Şefik and Heathcliff become restless and disturbed by the expectations of the society and their own social status. Although Heathcliff is "embraced by Mr Earnshaw as the son after his own heart" (Melikoğlu 1998: 53) and Şefik is treated as "a real son”, they are in need of approval, acceptance, wealth and power. Even though, unlike the in the western societies, there was not a distinctive social class division in the Ottoman society, social background and wealth were the main concerns in marriage arrangements. In Yeryüzünde bir Melek, in order to deserve the upper class woman, Raziye, Şefik is aware that a respectable social status, wealth and power are required both by the society and by Raziye's father. That is why, he decides to get education in Paris, leaving Raziye 
behind. However, in Paris, he suspends his letters because he believed it is essential for him to "complete our humanity and science first, then deal with love" (Ahmet Mithat Efendi 2000: 44) 2. After three years, due to the ignorance of Şefik and oppressions of her father, Raziye accepts to marry İskender Bey, a wealthy old man. Meanwhile Şefik returns as a reputed doctor. The first reason that Şefik fails to declare his love is based on his complex of inferiority, created by the society. Secondly, he believes that he does not deserve Raziye, the daughter of his custodian because Şefik considers Raziye as "the gift of God"' (Ahmet Mithat Efendi 2000: 22) 3.

In a similar way to Şefik, Heathcliff leaves the estate for three years because he is also aware of the class distinction, which is an obstacle in their relation. While Edgar represents the civilized life with his social class and attitudes, Heathcliff is the opposite because he is an outcast, an orphan without money and future. When he learns that Edgar has proposed Catherine, he compares himself with Edgar: "But, Nelly, if I knocked him [Edgar] down twenty times, that wouldn't make him less handsome, or me more so. I wish I had light hair and a fair skin, and was dressed, and behaved as well, and had a chance of being as rich as he will be!” (Brontë 1965: 97). After his return as a wealthy and powerful man, Heathcliff longs for revenge both from the society and Catherine, who prefers Edgar as a husband. In both novels, it is observed that relations are destroyed by the societies and families, which impose the social codes of the 19th century British and Ottoman societies. Although the decisions of female characters are considered as the act of "freewill", the society and parents pave the way to their choices in marriage. Catherine and Raziye have admiring feelings for Heathcliff and Şefik, however, they are forced to deny their desires due to societal expectations and oppressions.

In Yeryüzünde bir Melek and Wuthering Heights, the relations between the lovers are ruined by the societies, which involve a common social code: women were expected to marry socially acceptable and wealthy men to gain status and respect in society. As stated before, for Freud, the environment had an undeniable effect on the psychological development of an individual who could struggle between his/her desires and the expectations of the external world (Freud 1962b, 14). For him, this clash between the self and the oppressive and restrictive environment could be accepted as the core of the problems of individuals. In the Ottoman society, for instance, parents would choose the spouses to approve their daughters' marriages. In Yeryüzünde bir Melek, Ahmet Mithat Efendi criticized this 'forced marriages' of his era as:

Raziye loved Şefik so deeply. Right? She still does. However, in our country, it is rare that girls marry the man they love, rather, they marry the men they have never seen their face before... In fact, they do not marry on their wills. Moreover, the husbands do not propose themselves. The men who tend to marry assign this duty to their relatives who ask to the relative of the women. Whatever they decide, women accept as if they were not the ones to marry (Ahmet Mithat Efendi 2000: 50). 4

Similarly, Catherine is manipulated by the society that accepts Edgar as a perfect match and Catherine denies her desires for Heathcliff and marries to become a "civilised lady" (Figes 1990: 143). Although Catherine is highly aware of her mistake, she uses the "denial" as a defence mechanism to protect her ego from sorrow and oppressions of the Victorian society: "To-day, Edgar Linton has asked me to marry him, and I have given him an answer -Now, before I tell you whether it was a consent or denial-you tell me which it ought to have been" (Brontë 1965: 117-118). Upon her words, Nelly asks Catherine why she has accepted the proposal and Catherine cannot find a sensible reason until she declares that: "And he [Edgar] will be rich, and I shall like to be the greatest woman of the neighborhood, and I shall be proud of having such a husband" (Brontë 1965: 118). When Nelly reminds her Heathcliff, Catherine continues denying her real feelings: "I should only pity him-hate him, perhaps, if he were ugly, and a clown" 
(Brontë 1965: 119) and "it would degrade me to marry Heathcliff, now; so he shall never know how I love him; and that, not because he's handsome, Nelly, but because he's more myself than I am" (Brontë 1965: 121). Catherine chooses Edgar and sublimated her love to respectability with a reasonable behaviour rather than her desires:

To Catherine, psychological security means having not only a partner, but having one that is wealthy and socially acceptable. According to $19^{\text {th }}$ century custom, a woman was not 'complete' unles she married successfully. Heathcliff is barely capable of supplying himself with food and shelter, and so Catherine's eyes stray towards Linton (Goodlett 1999: 124).

Therefore, both Raziye and Catherine challenges the societal oppressions by denying their own pleasures and tend to find excuses to defend their social identities. In other words, both protagonists were forced to ignore their desires (the ids) to provide the expectations of society (the superegos) and defend themselves (the egos). In Yeryüzünde bir Melek, Raziye defends herself claiming that she has obeyed her father's decision because Şefik has abandoned her alone. However, she fails to deny her desires when the lovers meet in the woods:

Şefik: Not might be, but I am really glad. In fact, he is just your husband. However, I am everything to you. Right, my Raziye? Aren't I everything but husband to you?

Raziye - ...Yes, my Şefik! Both my heart and my body are yours. As you said you are everything to me but a husband! (Ahmet Mithat Efendi 2000: 16-17) 5

Catherine in Wuthering Heights also finds an excuse for her mistake and convinces herself that by marrying Edgar, she helps Heathcliff: "Nelly, I see now, you think me a selfish wretch, but did it never strike you that, if Heathcliff and I married, we should be beggars? Whereas, if I marry Linton, I can aid Heathcliff to rise, and place him out of my brother's power?” (Brontë 1965: 122). However, for Watson (1949: 93-94), "When she [Catherine] makes her fatal confession to Ellen [Nelly Dean], not once does she consider the effect of her choice on Heathcliff. She assumes that she can continue to rule both Edgar and Heathcliff". Similar to Raziye, Catherine struggles between her feelings and society (the id and the superego), yet, in order to protect herself, she marries Egdar as a husband: "Catherine ...betrays her own feelings, marries out of desire for social respectability and suffers wretchedly because of it” (Kiely 1993: 33). Although Catherine has a deeper love for Heathcliff, she defends her choice by persuading both others and herself as:

My love for Linton is like the foliage in the woods: the time will change it, I'm well aware, as winter changes the trees. My love for Heathcliff resembles the eternal rocks beneath-a source of little visible delight, but necessary. Nelly, I am Heathcliff! He's always, always in my mind- not as a pleasure, any more than I am always a pleasure to myself, but as my own being (Brontë 1965: 122).

Although both Raziye and Catherine have deep feelings for the orphans they grew up together, both female protagonists deny admitting their love to protect their social status by accepting the social norms and expectations. Also, torn between their feelings and the social expectations, both women suffer due to a clash between their ids and superegos. Therefore, to avoid frustration and sorrow, both Catherine and Raziye use denial as a defence mechanism to protect their egos.

The other similar reflected defence mechanism in Yeryüzünde bir Melek and Wuthering Heights is the "projection", a method of defence mechanism which refers the act of putting the blame on others to avoid fault, regret and sorrow. The individual first recognizes the reality of his/her own attitude and then represses the unacceptable impulses by attributing them to others. In other words, the ego learns what is regarded as blameworthy and protects the self from unpleasant self-criticism (Freud 1946: 128). 
Projection is putting the blame on others to avoid facing fault and sorrow. Catherine fails to recognize the realities, represses her desires and blames Heathcliff about her illness instead of accepting her mistaken marriage: "He [Heathcliff] does not know what being in love is" (Brontë 1965: 121). After her illness, Catherine blames Heathcliff and Edgar and projects her mistake:

You and Edgar have broken my heart, Heathcliff! And you both come to bewail the deed to me, as if you were the people to be pitied! I shall not pity you, not I. You have killed me-and thriven on it, I think. How strong you are! How many years do you mean to live after I am gone?” (Brontë 1965: 195).

Similarly, Raziye admits that she "never loved İskender Bey as much as she did for Şefik" (Ahmet Mithat Efendi 2000: 52) ${ }^{6}$ and that her soul still belongs to Şefik. However, she accuses Şefik for their tragedy: "Only if you had supported and continued this love with letters... why did not you write even a letter?" (Ahmet Mithat Efendi 2000: 14-15) 7

The only difference between Raziye and Catherine is observed in terms of the endings of the novels. Catherine suffers from brain fever and hysteria because Edgar refuses to "tolerate" Heathcliff. She is "selectively forgetting about whatever is troubling her" (Lynn 1998: 178) and escapes to her happy childhood in Wuthering Heights with Heathcliff. Due to hallucinations, Catherine is unable to recognize herself on the mirror: "Don't you see that face?" she enquired, gazing earnestly at the mirror... It is behind there, still! And it stirred. Who is it? I hope it will not come out when you are gone! Oh! Nelly, the room is haunted. I'm afraid of being alone!” (Brontë 1965: 161). In the end, after the birth of her daughter, Catherine dies. The novel ends while the ghosts of Catherine and Heathcliff unite in heaven. Raziye, on the other hand, in Yeryüzünde bir Melek, is punished by the society due to her forbidden love and suffers in poverty after the divorce. However, after many years, Şefik and Raziye unite and get married.

\section{Conclusion}

The relation between psychology and literature has been one of the most notable topics for authors who tend to give insights to their characters and events. The theories and studies of modern psychiatrists and psychologists indicate that social norms and environment shape the personality of an individual from childhood and puberty. In order to avoid frustration, isolation and sorrow, thus, individuals both make decisions appropriate for the social expectations and tend to protect themselves from undesirable feelings as guilt, shame, sorrow, frustration and anxiety via certain defence mechanisms. Freud, as the innovator of "defence mechanisms", stated that in order to protect the ego from stress and anxiety, the individuals use defence mechanisms to reduce anxiety caused by the unacceptable stimuli. Based on the studies of her father, Sigmund Freud, Anna Freud developed the categories of defence mechanisms of the ego in her book The Ego and the Mechanisms of Defence (1936). Freud (1946: 74), categorized the methods of defence mechanisms and explained that the defence mechanisms are the measures designed to "secure the ego and save it from experiencing pain or unendurable ideas".

In literary canon, the studies based on the relation between literature and other fields of social sciences have gained momentum and analysis of texts within a psychoanalytical approach has become notable. Many authors prefer to depict the psychological states of their literary characters similar to the individuals who tend to use defence mechanisms to avoid sorrow and frustration in actual life. In this study, the main aim is to demonstrate how "denial" and "projection", two of the defence mechanisms categorized by Anna Freud, shape the destinies of Raziye in Ahmet Mithat Efendi's Yeryüzünde bir Melek and Catherine in Emily Brontë's Wuthering Heights. 
In both novels, female protagonists, Catherine and Raziye repress their desires and feelings (the ids) to protect themselves (the egos) against the societies (the superegos). Raziye is unable to defend her love for Şefik and accepts to marry a wealthier socially accepted man while Catherine fails to defend her love for Heathcliff against "her" society. The second defence mechanism used both by Catherine and Raziye is "projection". Instead of accepting their mistakes, both project the sorrow of past on others. Catherine blames Heathcliff and Edgar for her misery in Wuthering Heights and Raziye accuses Şefik of his ignorance that causes her marriage with İskender.

\section{Endnotes}

1-7 The extracts taken from the text were translated by the author of this article.

\section{References}

Adler, Alfred (1964). Superiority and Social Interest. In H. L. Ansbacher \& R. R. Ansbacher (Eds.), A Collection of Later Writings. Evanston IL: Northwestern University.

Ahmet Mithat Efendi (2000). Yeryüzünde bir Melek. Türk Dil Kurumu.

Aytar, Abide Güngör (2005). Toplumsal ve Duygusal Gelişim. In A. Ulusoy (Ed.), Gelişim ve Öğrenme (93-126). Ankara: Anı Yayıncilık.

Brontë, Emily (1965). Wuthering Heights. England: Penguin Books.

Erikson, Erik H. (1968). Identity: Youth and Crisis. New York: W. W. Norton.

Erikson, Erik H. (1978). Adulthood. New York: W. W. Norton.

Figes, Eva (1990). Sex and Subterfuge: Women Writers to 1850. Oram Press: Pandora.

Freud, Anna (1946). The Ego and the Mechanisms of Defence. (Trans. C. Baines). New York: International Universities. (Original work published, 1936)

Freud, Sigmund (1962a). The Ego and the Id. (Trans. J. Riviere). London: The Hogarth and the Institute of Psycho-Analysis. (Original work published 1923)

Freud, Sigmund (1962b). Civilization and Its Discontents. (Trans. J. Strachey). New York: W.W. Norton.

Goodlett, Debra (1999). Love and Addiction in Wuthering Heights. Readings on Wuthering Heights. San Diego: Greenhaven.

Hossain, Mahroof (2017). Psychoanalytic Theory used in English Literature: A Descriptive Study. Global Journal of Human-Social Science: Linguistics \& Education, 17(1), 41-42.

Kefeli, Emel (2013). Bir toplum mühendisi olarak Ahmet Mithat Efendi. Yeni Türk Edebiyatı, 7(1), 2735 .

Kiely, Robert (1993). Wuthering Heights. In H. Bloom (Ed.), Heathcliff (pp. 33-35). New York: Chelsea House.

Kraus, Wolfgang (1982). Sigmund Freud ve Yazın. Yazko Çeviri, 6, 76-92.

Lynn, Steven (1998). Texts and Contexts: Writing about Literature with Critical Theory. New York: Longman.

Melikoğlu, Esra (1998). Allies and Antagonists: The Ambivalent Relationship between the Servant and the Child of the house in Nineteenth-century Literature. İstanbul: TürkKütüphaneciler Derneği.

Rennison, Nick (2001). The Pocket Essential Freud \& Psychoanalysis. Harpenden: Pocket Essentials.

Schultz, Duane \& Schultz, Sydney (Eds.) (2017). Theories of Personality. Australia: Cengage Learning.

Taylor, Graeme J. (2003) Somatization and Conversion: Distinct or Overlapping Constructs. The Journal of American Academy of Psychoanalysis and Dynamic Psychiatry, 31(3), 487- 508. 
1088 / RumeliDE Journal of Language and Literature Studies 2021.25 (December)

Defence mechanisms in literature: Wuthering Heights and Yeryüzünde bir Melek / S. Üstün Kaya (pp. 1079-1088)

Watson, Melvin R. (1949). Temptest in the Soul: The Theme and Structure of Wuthering Heights. Nineteenth Century Fiction, 4(2), 87-100. JSTOR. Web. 27 Feb. 2011

Yücel, Tahsin (2000). Ruhçözümleyim ve Yazın Eleştirisi. Milliyet Sanat Dergisi, 479, 7. 